\title{
Erythrocytic galactose-1-phosphate uridyl transferase levels in hepatic cirrhosis
}

\author{
M. M. FISHER ${ }^{1}$, S. SPEAR, E. SAMOLS, AND SHEILA SHERLOCK \\ From the Department of Medicine, Royal Free Hospital, London
}

EDITORIAL SYNOPSIS Hereditary galactosaemia is an inborn error of metabolism and may lead to the development of hepatic cirrhosis. The diagnosis may be established by finding very low or no levels of 'transferase' in the red cells. No examples of this disease were found among the patients studied and, it must be a rare cause of cirrhosis in Great Britain. It would seem adequate to screen cirrhotic patients by 'transferase' assay only if they showed other features suggesting galactosaemia. These include subnormal mentality, cataracts, a family or past history of intolerance to milk, or a family history of cirrhosis.

Hereditary galactosaemia is an inborn error of metabolism associated with a severe deficiency or absence of galactose-1-phosphate uridyl transferase (Kalckar, Anderson, and Isselbacher, 1956). This inability to metabolise galactose-1-phosphate causes the characteristic clinical features, which in typical cases appear soon after birth. Vomiting and jaundice are followed by cirrhosis, ascites, lenticular cataracts, and mental retardation if galactose is not eliminated from the diet (Donnell, Bergren, and Cleland, 1960). However, it has recently been shown that galactosaemia may in, fact, be the cause of cirrhosis in adults with normal intelligence and no obvious intolerance to milk (Hsia and Walker, 1961). Such cases have been revealed by studies of the families of known galactosaemic infants and suggest that incomplete expression of galactosaemia could occasionally be the cause of cirrhosis in adults.

The diagnosis of galactosaemia may be established by finding very low or no levels of 'transferase' in the red cells of affected subjects (Anderson, Kalckar, Kurahashi, and Isselbacher, 1957). Very little is known about the erythrocyte 'transferase' level in cirrhosis, as, except for one case of post-necrotic cirrhosis (Anderson et al., 1957), all such studies have been confined to cirrhosis in galactosaemics. Galactose tolerance tests are of little diagnostic value, for cirrhosis itself causes impaired galactose tolerance.

The present work was undertaken to assess galactose-1-phosphate uridyl transferase levels in the various types of adult cirrhosis with a view to revealing hitherto unrecognized instances of hereditary galactosaemia.

${ }^{1}$ Medical research fellow, Medical Research Ccuncil, Canada.

\section{METHODS}

Galactose-1-phosphate uridyl transferase was assayed according to the method of Bretthauer, Hansen, Donnell, and Bergren (1959), a modification of the original uridine dyphosphoglucose(U.D.P.G.) consumption test of Anderson et al. (1957). Routine biochemical tests of liver function were performed using standard procedures (Sherlock, 1963). Thirty normal subjects were studied. The group of patients with chronic liver disease included 22 patients in whom cirrhosis was of the active 'juvenile' or 'autoimmune' type (Read, Sherlock, and Harrison, 1963), five primary or secondary biliary cirrhotics, two in whom cirrhosis was cryptogenic in origin, and seven alcoholics. The group was completed by three patients with Wilson's disease. The diagnosis was confirmed in all cases by study of hepatic histology. All grades of severity of liver disease were represented in the 14 males and 25 females, whose ages ranged from 14 to 69 years. None of the patients had received blood tranfusions within three months of performing the assay. This procedure can temporarily give the galactosaemic patient a normal blood level of the enzyme. In addition, four galactosaemic children and one family study provided abnormal homozygous subjects for comparison.

\section{RESULTS}

The normal range for the 'transferase' assay in 18 male and 12 female subjects under the age of 42 years, including 12 under 20 years, was 13.9 to 26.8 (mean 20.3) $\mu$ moles U.D.P.G. consumed per gram haemoglobin per hour of incubation (Table I). The error of triplicate assays was $\pm 2 \mu$ moles U.D.P.G./g. haemoglobin/hour. These figures agree well with the results of Bretthauer et al. (1959) whose range of 14.7 to 25.4 (mean value 18.8 ) was based on 11 estimations. 
TABLE I

ERYTHROCYTE GALACTOSE-1-PHOSPHATE URIDYL TRANSFERASE ACTIVITY IN NORMAL AND CIRRHOTIC SUBJECTS STUDIED

\begin{tabular}{|c|c|c|c|c|c|c|}
\hline \multirow[b]{2}{*}{ Subjects } & \multirow[b]{2}{*}{ Male } & \multirow[b]{2}{*}{ Female } & \multirow[b]{2}{*}{ Age Range (yr.) } & \multicolumn{3}{|c|}{$\begin{array}{l}\text { Transferase Activity ( } \mu \text { moles U.D.P.G. consumed } / g \\
\text { Hb/hr. of incubation) }\end{array}$} \\
\hline & & & & Mean & Range & S.D. \\
\hline $\begin{array}{l}\text { Normal } \\
\text { Active 'juvenile' cirrhosis } \\
\text { Cirrhosis of the alcoholic } \\
\text { Cryptogenic } \\
\text { Wilson's disease } \\
\text { Biliary cirrhosis }\end{array}$ & $\begin{array}{r}18 \\
8 \\
5 \\
0 \\
1 \\
0\end{array}$ & $\begin{array}{r}12 \\
14 \\
2 \\
2 \\
2 \\
5\end{array}$ & $\begin{array}{r}1 / 12-42 \\
15-69 \\
34-61 \\
47-51 \\
14-19 \\
49-63\end{array}$ & $\begin{array}{l}20 \cdot 3 \\
20 \cdot 4 \\
19 \cdot 8 \\
14 \cdot 3 \\
17 \cdot 7 \\
18 \cdot 6\end{array}$ & $\begin{array}{l}13 \cdot 9-26 \cdot 8 \\
12 \cdot 4-28 \cdot 7 \\
14 \cdot 8-29 \cdot 0 \\
12 \cdot 2-16 \cdot 4 \\
13 \cdot 9-20 \cdot 4 \\
13 \cdot 5-21 \cdot 3\end{array}$ & $\begin{array}{l}3 \cdot 65 \\
3 \cdot 83 \\
4 \cdot 85 \\
- \\
-\end{array}$ \\
\hline
\end{tabular}

TABLE II

RESULTS OBTAINED IN GALACTOSAEMIA AND IN THE FAMILY OF A GALACTOSAEMIC

Subject Sex Age (yr.) Transferase and Activity ( $\mu$ moles
U.D.P.G. consumed/g. Hb/hr. of incubation)

\begin{tabular}{lllr}
\hline St. B. & M & $11 / 365$ & $1 \cdot 5$ \\
L. Br. & F & $3 \frac{1}{2}$ & $2 \cdot 0$ \\
M. Be. & M & $4 \frac{1}{2}$ & $2 \cdot 2$ \\
Hy & F & $1 / 12$ & 0 \\
Father of Hy & M & 31 & $7 \cdot 1$ \\
Mother of Hy & F & 31 & $9 \cdot 7$ \\
Sister C of Hy & F & 3 & $9 \cdot 0$ \\
Sister L of Hy & F & 6 & $14 \cdot 1$
\end{tabular}

In contrast, the four galactosaemic children had values of $0,1 \cdot 5,2 \cdot 0$, and $2 \cdot 2 \mu$ moles U.D.P.G. consumed/g. haemoglobin/hour of incubation (Table II). These figures emphasize that galactosaemics often have some 'transferase' activity, at least with the present techniques for assay of the enzyme. The family study of patient $\mathrm{Hy}$ is in keeping with an autosomal recessive inheritance. Both parents and one sibling are within the heterozygote range (about 7 to $14 \mu$ moles U.D.P.G./g. haemoglobin/hour) and the 'transferase' activity in the remaining sibling is in the lower range of normal.

None of the 39 patients with various types of cirrhosis (apart from Wilson's disease) were obviously of subnormal intelligence; they had all attended normal schools. None had cataracts. They gave no history of intolerance to milk. Urines did not give positive tests for reducing substances.

The 22 patients with active 'juvenile' cirrhosis (active chronic hepatitis) gave values within the normal range. In one case the value was insignificantly lower, 12.4 compared with the lower normal limit of 13.9. This patient had no other clinical features suggesting galactosaemia. Six of the patients were less than 20 years old.

One of the two patients with cryptogenic cirrhosis showed a value slightly and insignificantly below normal $(12 \cdot 2)$ but there were no supporting clinical features suggesting galactosaemia.
The seven alcoholic patients, the three patients with Wilson's disease, and the five biliary cirrhotics all gave results within the normal range.

The groups contained patients with and without jaundice, ascites, and hepatic precoma. There was no correlation between the enzyme result obtained and the clinical features or serum bilirubin, albumin, or glutamic oxalacetic transaminase levels.

\section{DISCUSSION}

This study has established that erythrocyte 'transferase' levels are essentially normal in cirrhosis, regardless of the nature and activity of the disease process. As there is no increase in 'transferase' this 'enzyme' does not hypertrophy to compensate for inadequate hepatic metabolism of galactose. As there is no decrease, the diagnostic validity of 'transferase' estimations in cirrhotics with no other features of galactosaemia is established. Rare exceptions do occur, as Schwarz, Wells, Holzel, and Komrower (1961) have reported three cases of classical clinical galactosaemia with normal levels of erythrocyte 'transferase'. The recognition of galactosaemics among the whole group of cirrhotics is clearly important, for such patients can be offered specific treatment. The position is analogous to the recognition of patients with Wilson's disease among patients with juvenile cirrhosis (Fisher and Sherlock, 1964). Galactosaemics with cirrhosis have been recognized after infancy. This, however, is usually part of a family study, the 11 cases of galactosaemia first diagnosed older than 12 years all being found in this way (Durand and Semach, 1955; Kalckar et al., 1956; Hugh-Jones, Newcomb, and Hsia, 1960; Walker, Hsia, Slatis, and Steinberg, 1962). Four of these subjects were more than 20 years old, including a 65-year-old grandfather with cirrhosis and cataracts. It was therefore rather disappointing that our survey of 39 patients with cirrhosis should have been so negative, especially as so many in the younger age group were included. Galactosaemia must be a rare cause of cirrhosis in Britain. It would seem 
adequate for practical purposes to screen cirrhotic patients by 'transferase' assays only if they showed other features suggesting galactosaemia. These include subnormal mentality, cataracts, a family or past history of milk intolerance, or a family history of cirrhosis.

\section{SUMMARY}

Galactose-1-phosphate uridyl transferase, the enzyme deficient in hereditary galactosaemia, was measured in the erythrocytes of $\mathbf{3 0}$ normal subjects and found to be 13.9 to $26.8 \mu$ moles U.D.P.G./g. haemoglobin/ hour. Twenty-two patients with active 'juvenile' cirrhosis (chronic hepatitis) seven with cirrhosis of the alcoholic, five with primary biliary cirrhosis, three with Wilson's disease, and two with cryptogenic cirrhosis gave values which did not differ significantly from the normal. None showed any other clinical features suggesting galactosaemia.

Galactosaemia must be a rare cause of cirrhosis in Britain. The transferase assay screening is indicated in any cirrhotic patient showing other stigmata of galactosaemia or with a family history of the disease.

\section{REFERENCES}

Anderson, E. P., Kalckar, H. M., Kurahashi, K., and Isselbacher, K. J. (1957. A specific enzymatic assay for the diagnosis of congenital galactosemia. 1. The consumption test. J. Lab. clin. Med., 50, 469-477.

Bretthauer, R. K., Hansen, R. G., Donnell, G., and Bergren, W. R. (1959). A procedure for detecting carriers of galactosemia. Proc. nat. Acad. Sci. (Wash.), 45, 328-331.

Donnell, G. N., Bergren, W. R., and Cleland, R. S. (1960). Galactosemia. Pediat. Clin. N. Amer., 7, 315-332.

Durand, P., and Semach, F. (1955). Formes tardives, attenuées de galactosémie chez deux frères; interprétation clinique et classement génétique de la maladie. Arch. franc. Pédiat., 12, 958-971.

Fisher, M. M., and Sherlock, S. (1964). Familial hepatic copper storage disease: A variant of Wilson's disease. Arch. Dis. Childh., 39, 14-17.

Hugh-Jones, K., Newcomb, A. L., and Hsia, D. Y. (1960). The genetic mechanism of galactosaemia. Ibid. 35, 521-528.

Hsia, D. Y., and Walker, F. A. (1961). Variability in the clinical manifestations of galactosemia. J. Pediat., 59, 872-883.

Kalckar, H. M., Anderson, E. P., and Isselbacher, K. J. (1956). Galactosemia, a congenital defect in a nucleotide transferase. Biochim. biophys. Acta (Amst.), 20, 262-268.

Read, A. E., Sherlock, S., and Harrison, C. V. (1963). Active 'juvenile' cirrhosis considered as part of a systemic disease and the effect of corticosteroid therapy. Gut, 4, 378-393.

Schwarz, V., Wells, A. R., Holzel, A., and Komrower, G. M. (1961). A study of the genetics of galactosaemia. Ann. hum. Genet., 25, 179-188.

Sherlock, S. (1963). Diseases of the Liver and Biliary System, 3rd ed. Blackwell, Oxford.

Walker, F. A., Hsia, D. Y., Slatis, H. M., and Steinberg, A. G. (1962). Galactosemia: a study of twenty-seven kindreds in North America. Ann. hum. Genet., 25, 287-311. 